\title{
Sponsor networks and business relations orchestrated by team sports clubs
}

\begin{tabular}{|r|l|}
\hline Journal: & Sport, Business, Management: an International Journal \\
\hline Manuscript ID & SBM-07-2016-0030.R2 \\
\hline Manuscript Type: & Research Paper \\
\hline Keywords: & $\begin{array}{l}\text { Small businesses, survey, team sports club management, Network theory, } \\
\text { Business-to-business }\end{array}$ \\
\hline Authors: Ulrik Wagner, H Thomas R Perssons, and Marie Overbye \\
\hline
\end{tabular}

\section{SCHOLARONE ${ }^{\text {m }}$ \\ Manuscripts}




\section{Sponsor networks and business relations orchestrated by team sport clubs}

\section{Purpose}

This study investigates firms' reasons and motives for becoming sponsors and how they benefit from this networking engagement by exploring sponsorship networks associated with two Danish team sport clubs - a Premier League football club and a second-division handball club.

\section{Design/methodology/approach}

Two online surveys were conducted with firms associated with the networks during the autumn and winter of 2013/14 $(N=116)$. The questionnaire was theoretically anchored in existing sponsorship literature, business network research and social capital theory.

\section{Findings}

The results show that business logics were the dominating reasons for joining the network. A large proportion of the respondents reported having increased their number of business $(32 \%)$ and social (26\%) relations with other network members after joining the network.

Furthermore, $37 \%$ of the respondents reported having made business agreements with companies external to the network via network contacts, which supports ideas of bridging social capital. More than half the respondents (59\%) preferred doing business with network members rather than with non-members.

\section{Originality/value}

By investigating a local and regional sport-club context, the paper adds to our knowledge about sponsorship networks. It emphasizes the potential importance of team sport clubs for the business landscape, thus maintaining that sport clubs fulfill an important role for local communities beyond being mere entertainment industries. 
Keywords: Small businesses, survey, team sport club management, network theory, social capital, business-to-business.

Paper type: Research paper 


\section{Introduction}

Sponsorship management no longer focuses solely on reaching consumers by promoting products in the mass media. More recently, study has been devoted to sponsorships as an arena of network management (Ryan and Fahy, 2012). Whilst the mainstream of B2B network research has either focused on traditional networks such as supply chain networks (Capó-Vicedo et al., 2011) or determined types of networks by using categories such as geographic proximity, same industry, interactions with intended business outcomes (Human and Provan, 1997; Wincent et al., 2010), B2B networking facilitated by professional team sport clubs has been neglected. For sport organizations attracting sponsors through businessto-business networking opens the door to a new source of potential income: In an open league structure clubs always face the threat of being relegated, which often leads to situations of severe income reductions due to decreased media exposure. Hence, focusing solely on good sporting results as a strategy for income generation is associated with uncertainty. Instead, from the perspective of a sport club - that may not always belong to the best league establishing a business-to-business network arrangement with sponsors that goes beyond mass-media exposure can prove financially beneficial for clubs in periods of poorer sporting results. From the point of view of businesses, sport-related networks may be viewed as alternatives or as additions to more traditional business networks. Inter-organizational relations made up by sponsors may be one such type of network. Research shows that the importance of being part of a network holds true for entrepreneurial start-ups just as it does for established small and medium-sized enterprises (SMEs), (Pirolo and Presutti, 2010; Street and Cameron, 2007; Sullivan and Marvel, 2011). Therefore, the overall purpose of this paper is to investigate empirically sponsor networks and business relations orchestrated by team sport clubs, which has so far received limited attention.

In recent decades sponsorship research has evolved to become a pivotal topic within 
marketing research (Cornwell, 2008, 2014; Cornwell and Maignan, 1998; Walliser, 2003), and over time the strategic use of sponsorships has gained increasing interest among researchers (Demir and Söderman, 2015). The design of sponsorships today seeks new ways to create value for the parties involved, which includes using networks as one of the more recent forms of establishing sponsor-sponsee relations (Ryan and Fahy, 2012). By investigating sponsorships in relation to network creation, this study unites a recent but hitherto scarcely exposed strand within sponsorship research literature with the business network literature. Thus, the aim of our study is to explore why and how firms engage in these sponsor networks and, on the basis of these insights, to discuss the role of and challenges for team sport clubs in facilitating and managing these networks. By using quantitative data from two Danish sponsor networks, this study meets its aims through investigating: 1) motives for becoming a sponsor; 2) reasons for participating in network meetings and the degree to which business-oriented reasons are assessed and preferred to social or sporting motives; 3 ) business creations and agreements achieved via network engagement as well as changes in the number of business agreements and personal relations prior to and after entering the network; and 4) whether or not membership of the network has favored doing business with other network members.

The study is based on two cases: one football club belonging to the highest Danish league during the 2013/14 season and one handball club figuring among the top teams in the second-highest Danish division during the $2013 / 14$ season. Whilst this study is an exploratory pilot study covering only two networks, the ambition is to carry out an extended study in the future covering all Danish clubs hosting similar networks. The clubs in this study are situated on the periphery of Denmark, which is characterized by relatively low economic growth rates, a stagnant housing market, and above-average unemployment rates. Football and handball belong to the most popular and traditional team sports in Denmark in terms of participation, 
mass-media promotion, sponsorship attractiveness, and the players' level of professionalization. A common and standardized feature of professional Danish handball and football clubs is that they have established networks of sponsors and business partners associated with the team and the club. Theoretically, this study is embedded in network theory with a specific focus on SMEs, and it also draws on insights from the field of social capital theory and existing sponsorship and business-related literature. The research design provides the basis for our analysis and discussion of the potentials of sport club-related sponsor and business networks to create social networking and B2B relations, which enables us to contribute to the discussion of sport's role in facilitating and orchestrating business relations in local communities. We conclude by discussing the limitations and implications of managing sponsor networks. As a result, the study seeks to extend the scope of current sponsorship research as well as contributing to a better and more detailed understanding of the roles and perspectives for as well as the constraints of professional team sport clubs in local and regional business settings.

\section{From consumer orientation to network management: Insights from sport sponsorship} research

There is no archetypal sponsor. Instead, one may describe the variety of intentions behind sponsorship along a sliding scale between philanthropy or patronage with community goodwill and bona fide business partnerships (Farrelly, 2010). The most prominent and direct forms of sport sponsorship are still to be found in the act of exchanging money for logos on shirts and in-arena signage with stadium banners, aimed at increasing and enhancing awareness of brand image and reputation (Amis et al.,1999). Thus, sponsorship research is a well-established research field within sport management and in particular marketing (Cornwell, 2008; 2014; Walliser, 2003). The growth of sponsorships can be seen as an 
extension of traditional advertising. Accordingly, early contributions to sponsorship literature focused on how sponsorships could be regarded as a means of fulfilling classical marketing objectives such as product promotion and increasing consumer awareness (Ryan and Fahy, 2012). However, today sponsorships have multifaceted purposes such as human resource management (Farelly et al., 2012), city branding (Evens, 2003), or emphasizing corporate social responsibility (Flöter et al., 2016). While some researchers (Farrelly, 2010; Meenaghan, 1998; Miles, 2001) claim that they have detected an improvement in terms of applying a business approach to sponsorship, others (Chadwick and Thwaites, 2004: 50) argue that many corporations still engage in sponsorship for the association with the high end of sport.

Nonetheless, firms seem to engage in sponsorships much more strategically today than in the past (Demir and Söderman, 2015).

One way of benefiting from sponsorships strategically is by using them for networking purposes. This is in line with Ryan and Fahy (2012), who state that recent developments in the field of sponsorship include network management. Accordingly, the network approach highlights firms' capabilities of envisioning and orchestrating business-to-business creations. A network perspective also creates the foundation for business-to-business relationships between sport sponsors and sport entities for mutual benefit (Farelly et al., 2005; Henseler et al., 2011). Thus, network management becomes pivotal when the sponsored organization takes on the role as a bridge between organizations in the development of relationships (Kim et al. 2014). However, few contributions have so far looked at the role and functions of sponsor and business networks empirically (Olkkonen et al., 2000), and even fewer at B2B networks among sponsors with new business as an intended result. Exceptions to this, which focus on networks and sponsorships, do exist (e.g. Kim et al. 2014; Olkkonen, 2001). Investigating a network related to a Formula One team, Cobbs (2011) shows that a relational network approach reveals new inter-organizational potentials for the sponsors. In a similar 
way, Morgan et al. (2014) recently investigated an international sporting event in order to examine the relationship between the sporting event and its sponsors. One of their conclusions was "that as well as receiving financial benefits and brand associations, it is in the interest of the sporting body and sponsors to integrate strategic thinking and planning into their sponsorship relationships" (p. 280). Unlike the four above-mentioned sponsor network studies, which all examine high-profile international cases, our study explores regional network creations and local communities involving a majority of small business enterprises. In doing so, it adds an additional dimension to what can be termed the relational dynamics of sponsorships (Cornwell, 2008; Farrelly, 2010). Accordingly, knowledge about what motivates sponsors to join a network is a precondition for discussing inter-organizational expectations and benefits from sponsorship network engagement. Studies within relationship marketing like that of Morgan and Hunt (1994) emphasize trust and communication as significant variables supporting relationships. Contrary to this finding, Böhler et al. (2007) did not consider trust and effective communication to have an influence on the success of a sponsorship. Of interest to us is to explore what motivates firms to join less conspicuous sport club networks. One can argue that sponsorships today represent complex settings that require a multiple perspective, as suggested by Daellenbach et al. (2006). Following this logic, investigating sponsorship relations in terms of a network approach is only one among many approaches, but using this approach enables us, according to Daellenbach et al. (2006), to view network access as a gateway to exchanging structures and resource suppliers. Consequently, the next step is to embed these insights into sponsorship relations in a theoretical design that builds on networks as a crucial feature of the modern business landscape.

\section{Networks as the theoretical point of departure}


There is a common understanding that networks per definition are plural or hybrid forms of strategic alliances and cooperation (Rus and Iglic, 2005). The interest in, as well as research and literature on, networks is vast and includes - but is not limited to - positive and negative outcomes of trust (Brunetto and Farr-Wharton, 2007; Farrelly and Quester, 2003), their ability to generate new business and growth (Schoonjans et al., 2013), cooperation and innovation (Tomlins and Fai, 2013), brand image (Mäläskä et al., 2011), and relational marketing (O’Malley, 2014). There is a common understanding among small business alliances and network researchers that networking frequently has far-reaching implications for SMEs' success and profitability (Street and Cameron, 2007).

In their extensive review of networks Brass et al. (2004) argue that the network perspective differs from traditional perspectives in organizational studies because it does not examine individual actors in isolation. In adopting this perspective, we argue that relationships formed and facilitated in and by a network become the main analytical focus. We embrace the definition of a network as "a set of nodes and the set of ties representing some relationship, or lack of relationship, between the nodes" (Brass et al. 2004, p. 795). Thus, nodes can be defined as individual actors or organizations. In this paper we argue that relationships are formed by individuals but that, at the same time, these individuals are leading representatives of organizations included in the sponsor and business networks. Ties between the members of a network can take different shapes and forms depending on the network (Granovetter, 1973). The strength of the individual tie is facilitated and defined by trust and a "combination of the amount of time, the emotional intensity [...] and the reciprocal services which characterize the tie" (Granovetter, 1973, p. 1361). Although the quality of the network takes front seat, size is also likely to matter. While the size of a network ought to be related to the amount of new information spread within that network, a heterogeneous network is more likely to generate new information for the individual members than a 
homogeneous network made up of members that already share the same contextual information (Sullivan and Marvel, 2011). For example, a heterogeneous network may, as suggested by Björnfot and Torjussen (2012), take the form of complementary collaborations where actors in supply chains share knowledge and production resources, creating a collective strength that improves the individual suppliers' bargaining position vis-à-vis customers (see also: Capó-Vicedo et al., 2011; Tomlinson, 2011; Tomlinson and Fai, 2013).

Although the focus tends to be on networking, cooperation or alliances between businesses, some authors argue that it is the personal relationships between businesses that facilitate the success of diffusion and adaptation of innovation, which in turn increases the competitiveness of firms (Ceci and Iubatti, 2012). In similar fashion, MacGrath and O'Toole (2010) point out that the outcome is heavily dependent on the individual perception of the network as interconnected business relations or on personal contacts built on trust, commitment, and communication. Nevertheless, rather than being one or the other, i.e. social/personal or business-based relationships, Mäläskä et al. (2011) emphasize that it is the combination of social and business networks that contributes to strengthening the brand image of SMEs due to their regularly being directly or indirectly exposed to external influences. Consequently, networks and networking are about building, maintaining, and retaining relationships defined "as collaborative arrangements established via the interactions between actors embedded in a social context” (Sydow and Windeler, 2003 in Jørgensen and Ulhøi, 2010, p. 398). This applies to individuals and their private relations as well as to the business landscape (O’Malley, 2014; Webster, 1992). Thus, network research contains a multi-level perspective by investigating inter-personal as well as inter-organizational relationships (Brass et al. 2004). The concept of social capital has also become widely used to understand the importance of network relations for enterprises ( $\mathrm{Li}$ et al., 2013). The argument is that the mere existence of a relationship says nothing or little about its quality - and hence little about the 
firm's access to others' resources. The quality of the relationship is, in fact, crucial in motivating members of a network to share their resources and is only achieved through a high degree of interaction frequency and interaction intensity over time (Semrau and Werner, 2012). Considering the key role played by the sport as the network facilitator, we define social capital as the relational resources that we as individuals or as part of a collective, as well as organizations or companies, inherit or intentionally construct in order to achieve or own goals. Depending on structural and normative characteristics of the social system in which it operates, social capital can facilitate but also limit both individual and collective action

(Persson, 2008, p. 40)

The underlying philosophy of our research design is therefore underpinned by the relational character of networks. It is based on the idea of social embeddedness (Granovetter, 1985). Nodes are not perceived as being made up of isolated, context-free actors; nor are they pre-determined by existing social structures. Our dialectical perspective resembles much more a tradition known as relational sociology (Emirbayer, 1997) in which agency and structure mutually constrain, enable, and reproduce each other. This is done in order to position our research beyond methodological individualism and structural determinism (Giddens, 1984).

\section{Methodology}

The two cases

This study comprises empirical data from two sponsor networks connected to two Danish sport clubs: the football club FC Vestsjælland (henceforth FCV) and the handball club Team Sydhavsøerne (henceforth TSØ). Both clubs geographically belong to the Region Zealand, 
one of the five Danish regions. Furthermore, they are situated away from urban centers in a peripheral part of Denmark dominated by relatively high levels of unemployment, a stagnant housing market, limited economic growth and rapid de-industrialization over the last two decades (Kommunernes Landsforening, 2014). The two clubs were selected because they share certain specific traits: they are situated on the periphery of Denmark; they are both rather new clubs; they have elite superstructures, although they were founded on the grounds of long-established clubs; and they do not belong to the national elite within their respective sports. Although different sports, they represent the most popular team sports in Denmark. FCV was officially founded in 2008 with the explicit purpose of qualifying for the top Danish league, which the club managed after the 2012/13 season. The name refers to the region of western Zealand; and representing and unifying the region was one of the aims behind the club's establishment. The club was relegated after the 2014/15 season, and by the end of 2015 it had become bankrupt. During its successful period it had formalized partnerships with several clubs in the region and shared the characteristics of a merger club without actually being a merger between two existing clubs. Although the team belonged to the bottom of the Danish Premier League (PL), the FCV represented progress and success for a region that before the 2013/14 season had not been represented in the Danish PL since the late 1970s. From the very beginning the FCV had a network consisting of sponsors and business partners - a network primarily managed by volunteers. Nevertheless, after its promotion the club's marketing activities rapidly underwent a process of professionalization, including offering pre-match and ad hoc events for their network members.

TSØ is currently (2016/17 season) playing in the second-highest Danish handball division. The club, whose name refers to the islands in the south of the country close to the German border, was established in 2003, and in 2005 it was organized as a merger between the elite sport sections of two local clubs on an island with a longstanding handball tradition. 
The club has played twice in the qualifying games for the top Danish handball league (during the 2012/13 and 2013/14 seasons) but has not yet been successful. Like FCV, the club arranges pre-match events, networking meetings and ad hoc activities for their sponsor network members.

\section{Procedure, participants and measures}

\section{The questionnaires}

We selected an explorative and quantitative approach due to the limited empirical research into sponsor networks of sport clubs. Moreover, this enables an assessment of more general perspectives of corporate motives and companies' use of these networks. A link to a webbased questionnaire was distributed to representatives of the two sponsor and business networks of both FCV and TSØ by email, facilitated by the sponsor and business networks' managers (FCV: $\mathrm{N}=67$, response rate approx. 48\%; TSØ: $\mathrm{N}=49$, response rate approx. 39\%). Respondents were informed that the research was independently carried out by researchers from the University of Southern Denmark; that the research was being undertaken in dialogue with the club management in order to optimize the sponsor and business networks; and that their answers would be anonymized. Data was collected during the autumn and winter of 2013/14. Table 1 provides an overview of the number of employees as well as years in the network of the companies participating in this study.

:::::::::: INSERT TABLE 1 ::::::::::::::

\section{Measures}


The questionnaire contained questions about motives for becoming a sponsor, reasons for participating in network meetings, business creation and agreements achieved through network engagement prior to and after joining the network, as well as the number of social relations established through the network. The strength of the network is measured by whether the firms prefer to enter into business agreements with other network members and/or under which conditions the firm will choose to do so.

Motives: Some studies have revealed that corporate sponsorships are increasingly used strategically (Demir and Söderman, 2015) while others have found that philanthropic reasons and personal preferences of managers, e.g. 'being in it' for the sake of the sport (Slack and Bentz, 1996), or more CSR-oriented reasons also exist (Flöter et al. 2016). Therefore, the motives for becoming a sponsor were measured according to eight statements, four referring to social motives, encompassing social and philanthropic reasons, and four referring to business motives, encompassing strategic business purposes. Answer categories were: "great", "some" or "no" influence. In addition, respondents were given the possibility of replying "we do not believe it is like that".

Reasons for participation: Important contributions to the sponsorship literature claim that sponsorships can be turned into a distinctive competence (Amis et al. 1999). Combined with the notions that much of recent sponsorship engagement is about network orchestration (Fahy and Ryan, 2012) and that activating a sponsorship is one of the key elements in value creation through sponsoring (O'Reilly and Horning, 2013), we need to know which reasons the companies use for participating in network activities because this provides an indication of how the network is used by its members. This is a follow-up to the previous question investigating why they decided to engage in sponsoring. Accordingly, to assess their reasons for participating in network meetings, the respondents were asked to evaluate nine statements related to business orientation ( 3 items), social purposes (4 items) and a combination of both 
business and social reasons (2 items). Answer categories were: "great", "some" or "no" influence. Additionally, firms could answer: "We do not experience it like this".

Strength of the network: Networks are considered to be durable relations (Granovetter, 1973). From the network literature we know that several indicators need to be looked at (Brass et al. 2004). The strength of the network was assessed using different measurements: Firstly, we estimated aspects of the strength of the network by counting the number of business contacts with other network members prior to and after joining the network. In particular, respondents were asked to evaluate the volume of business creation and number of agreements achieved with other network members prior to and after joining the network. But as emphasized in our theory section, networks can have a form as both interpersonal as well as inter-organizational relations (Brass et al. 2004). In order to investigate both forms, we therefore also measured the number of social relations and business contacts established with other network members by asking the respondents to estimate the number prior to and after joining the network. Answer categories regarding the change in the number of business contacts and social relations after joining the network were: $0 ; 1-5 ; 6-10 ; 11-15 ; 16-20$ and more than 20.

Social capital: Although the number of ties may play an important role, it is most probably the heterogeneity of the network - and therefore the quality of ties - that will generate new contacts, new information, new resources, and new business (Sullivan and Marvel, 2011). Often, network theory lends insights from studies on social capital (Brass et al. 2004). A central claim is the observation that a relationship between two parties opens the door to a third party. Thus, to extend the focus on the number of contacts measured earlier, the questions which followed also asked whether business agreements had been made with companies outside the network by contacts gained via network engagement. In addition, this led to a further inquiry into whetherthese ties also induced its members to give priority to 
other networks members and, if so, under which conditions. Accordingly, the strength of the network was assessed by asking whether or not membership of the particular network induced respondents to prefer making business agreements with other network members. This was measured in seven items assessing the extent to which network members preferred relations with other members when doing business, for example with regard to price and quality.

\section{Data analysis}

Data was analyzed using SPSS22. Descriptive data are reported as frequencies and percentages. Bivariate nonparametric statistics were used to compare differences between respondents from the two networks. Differences were assessed using a chi-square test and gamma test (two-tailed); p-values of less than 0.05 were considered statistically significant.

\section{Findings}

Reasons for sponsoring

With regard to motives, the sponsoring firms were asked about their reasons for sponsoring FCV and TS $\varnothing$, and how they assessed business, social and sporting reasons (Table 2). The largest share (68\%) answered that using the network to make business deals was of great importance. A further common reason for sponsoring was related to the notion that it was important to support professional football/handball on West Zealand/ Lolland-Falster. Only a small number reported that the reason for sponsoring was because it had always been important to support the particular club. It must be noted that in this particular item a large number of respondents indicated that they did not experience it in such a way - thus suggesting that they disagreed that it had always been important to support the particular club. Surprisingly, less than half (45\%) reported that "using FCV/TSØ to advertise our firm/ organization and product(s)" was a reason of great importance for their sponsorship. 
::::::::: INSERT TABLE 2 :::::::::::::

\section{Reasons for attending network activities}

The next step was to investigate the firms' reasons for attending FCV's/TS $\varnothing$ 's business network activities and how business-related reasons were assessed compared with other social and sporting reasons (Table 3).

The reasons most respondents regarded as being of great importance for participating in network meetings were i) the opportunity to meet and interact with other businesses $(66 \%)$ and ii) to create opportunities for new businesses (61\%). A minority (13\%) regarded the possibility of missing out on important information as a reason of great importance. The opportunity to indulge in nice food and drink was not considered a reason for participating in network meetings for members of FCV (2\%), whereas $22 \%$ of TS $\varnothing$ respondents regarded this as a reason of great importance for their participation in network meetings.

\section{Business creation through network participation}

The following two sets of questions were designed to measure i) whether or not firms had increased their business and social relations with other sponsors/firms after joining the FCV and TSØ networks and ii) whether or not their participation in the networks had resulted in an increase in business with firms outside the network. This was our way of measuring the social capital achieved via network engagement, i.e. that a heterogeneous network opens a door to additional resources, contacts and information channels beyond the formal network itself. The first set of questions (Table 4) measured these aspects by asking the participants to estimate 
the number of business and private relations with network members prior to taking part in the network and the current number of relations. The subsequent set of questions (Table 5) measured whether networking with companies within the network had led to contacts outside the network (business-to-business arrangements) and the extent to which this was related to the number of years spent as part of the network.

Several of the firms participating in the survey stated that they had increased their business with network members after becoming members of the network. No significant differences were found between FCV and TS $\varnothing$ networks in the reported increase in the number of business deals between network members. Therefore, the results from the two networks were merged. Around one third $(32 \% ; n=35)$ of the sponsors reported an increase in their number of business with other members of the sponsor network since becoming a member; half $(50 \% ; n=55)$ reported doing business with approximately the same number of members; and 6\% $(n=7)$ reported doing less business with other members within the network than before becoming network members. A minority $(12 \% ; n=13)$ reported doing business with more than twenty other sponsors, before as well as after joining the networks. For these sponsors it was not possible to determine whether they were now in business with the same number of, more or fewer partners than before becoming network members (see Table 4).

::::::::: INSERT TABLE 4 ::::::::::::::

Several individuals representing the businesses included in the survey increased their private relations with network members after joining the networks. No significant differences were found between the FCV and the TS $\varnothing$ in the changes in numbers of social relations. Therefore, results from these networks were merged. One fourth $(26 \% ; n=28)$ of the sponsors increased the number of persons they met socially after becoming members of the network; $62 \%(n=67)$ met with approximately the same number of people; and $3 \%(n=3)$ reported a 
decrease in the number of persons they met with on social occasions. A minority $9 \%(n=10)$ of the sponsors met with 10 persons or more socially before and after joining the network. Among these it is impossible to determine whether this number changed (i.e. remained the same, decreased or increased) after they became members of the sponsor network (Table 5).

\section{Achieving business agreements with non-network members via network members}

When asked about new business agreements with non-network members, more than one third of the respondents (37\%) reported that they had made business agreements with companies outside the network by contacts gained via their network engagement. Nearly half (46\%) of the sponsors engaged in the network for more than two years reported that they had used their network contacts to make business agreements with companies outside the network. Among those respondents with two years or less in the network, only a minority $(13 \%)$ had as yet signed business agreements with non-network members due to contacts through the network.

To identify the degree to which membership of the network influenced business preferences, respondents were asked whether they would prefer to do business with other firms within the network rather than firms which were not part of the network, or whether this did not affect their decisions. Results showed that more than half of the respondents $(59 \%)$ would prefer to do business with network members rather than with non-members. Few respondents indicated that this would only be the case if the price was better $(6 \%)$ while one third (33\%) reported that they would prefer to do business with other network members rather than with non-members only if the price of the product was the same. Most network members would only prefer members over non-members when no differences were found in the quality of the product of the non-member (38\%) or if the quality of the product of the non-member 
was better (10\%). However, a minority $(14 \%)$ would prefer to do business with members over non-members, even if the price was higher (see Figure 1).

\section{Discussion}

The study was designed to investigate motives for becoming a sponsor, reasons for participating in network activities, business created by network engagement and whether membership of a network favored doing business with other members.

Firstly, this study confirms that sponsorship engagement goes beyond mere advertising: the motives for engaging in sponsor networks are first and foremost guided by the aim to enter into business deals rather than to use the connection with the club for advertising purposes. In line with Demir and Söderman (2015), the results of the current study reveal that business engagement is linked to the strategic use of sponsorships. However, it must be emphasized that the firms' support for local professional team sports is also given a relatively high level of support. Accordingly, although business reasons dominate, social motives (such as a local interest in supporting professional sport) also seem to contribute to a sponsor's commitment to networks. The local commitment perspective of this study is unique to the field since most other studies on sponsor networks deal with international high-profile events with sponsors not linked to a local community (Cobbs, 2011; Morgan et al., 2014; Olkkonen, 2001). On the other hand, the sponsorship literature is rich in examples of community engagement and local commitment (Wagner and Nissen, 2015; Zinger and O'Reilly, 2010); thus, our study on local networks links the network literature to sponsorship research. An important finding is that fewer than half of the firms surveyed (45\%) indicated that they gave great importance to advertising as a reason for joining the networks, which is in line with the overview provided by Ryan and Fahy (2012): the market- and consumer-centered approach is 
superseded in this particular context by an approach that emphasizes business-to-business interaction orchestrated by a network.

Secondly, in a similar way our study shows that the reasons for participating in network arrangements are dominated by business considerations. This suggests that sponsor networks function first and foremost as sites for concrete business-to-business interactions. Our study builds on and extends the insights provided by Street and Cameron (2007) as such networks may have far-reaching implications for a local community. The local sport club - despite not belonging to the national elite - is able to create business alliances between small businesses. Therefore, a sport club becomes a pivotal point for local enterprises and small-scale business interactions, and accordingly, its role in the local community is extended far beyond being merely a part of the entertainment industry on home-match days. This may explain why sponsors seem less stimulated by social reasons or a distinct sporting interest when asked to assess their reasons for participating in network arrangements.

Thirdly, the results of this study suggest that one way of measuring the strength of a network is to measure the increase in business agreements with other network members when a firm enters the network. One important finding is that the majority does not report increased numbers of relations (social as well as business) due to engagement with the network. According to the results of this study, then, the importance and potentials of these networks should not be over-emphasized. A recent study using Denmark as an example has also warned against 'over-selling' the positive argument of the economic potentials for local communities of hosting elite sport clubs (Storm et al. in press). Nonetheless, one third of the respondents stated that they had increased their business with other members after joining the network. If not the majority, a large proportion of firms seem - in their own assessment - to have benefited from their engagement by increasing inter-organizational business agreements with other network members. But, as pointed out by Ceci and Iubatti (2012), there is no clear 
distinction between business and personal relations; rather, we should see these as intertwined (Mäläskä et al., 2011). Approximately one fourth of the respondents stated that the number of their personal relations had increased as a result of their sponsor network engagement. This indicates, too, that a considerable minority gained new private relationships due to their network engagement while a larger proportion remained unaffected.

Fourthly, it is worth emphasizing that the majority of members do not report being positively prompted to engage with companies outside the network. Despite this, a notable finding is that more than one third of the respondents report that they had entered into business agreements with companies outside the network through their network engagement. This partly extends the scope of the business-to-business potential of a sponsor network since relations between two network members can pave the way for business relations with a third, non-network member partner. The time invested in the network also matters as companies associated with a club for over two years are more likely to have formed business relations with non-members. This finding indicates that it takes some time before a firm can benefit from its network engagement. Although our study is not able to identify how these relations are formed (as discussed by MacGrath and O'Toole, 2010), this is an interesting aspect for those firms using networks to engage with third parties as the implications of networking are extended beyond the network itself. Thus, it also provides a key insight into understanding the local and regional business landscapes. A possible explanation for using club facilitated networks is that these sponsor networks are heterogeneous and, as suggested by Bjönfoot and Torjussen (2012), will take the form of complementary collaborations. From the point of view of social capital theory, a heterogeneous network (which bridges social capital) will provide the opportunity to access new contacts beyond the network while the homogenous network will (in most cases) add neither new information nor new contacts. Thus, contrary to existing classical business networks, sport sponsor networks are perhaps far more inclusive as they 
recruit members beyond retail and small production companies to include local service firms, educational organizations, master craftsmen and cultural industries. For some network members this inclusiveness paves the way for contacts and ultimately contracts beyond the boundaries of the network itself, which seems to be the case for a large minority in our study.

A further means of identifying the strength of the network in our study was to ask whether, and under which conditions, network members preferred doing business with other network members. A majority of our respondents preferred doing business with members rather than with non-members. An interesting finding here was that one out of seven members were willing to give preference to other members even if the price was higher, thus indicating that for few companies the importance of belonging to a network trumps the classical economic assumption that firms strive to minimize costs and maximize profits. Although this statement must be interpreted with caution as it has not been tested when a firm is actually confronted with this decision (and is therefore of a hypothetical nature), it still gives us an indication of the strength of the network. One could interpret both answers - regarding contacts formed and contracts signed outside but through the network and the preference to do business with members over non-members - as being deeply imbedded in trust between network members and potentially underpinned by a high level of emotional intensity (Granovetter, 1973). The passion for sport, although not the most significant rationale for network engagement, can contribute with such emotional intensity familiar from studies on fan identification (Donovan et al., 2005).

\section{Conclusion}

This study explores the role of sponsor networks in local community settings, thus bridging sponsorship research with existing research on business networks. The study aimed at extending the scope of sponsorship research by contributing knowledge about the roles, 
perspectives and constraints of team sport clubs in relation to local business. Knowledge was contributed through the lens of network theory and by investigating the clubs' roles in facilitating local business-to-business interactions. Overall, our findings provide insights into corporate motives, the use of networks and potential outcomes of business-to-business relations in sport settings that are not connected with large-scale international sporting events but in settings that have a daily impact on the local and regional business landscape. Our findings confirm that firms engage in sponsor networks primarily for business reasons. This is consistent with existing strategic approaches to sponsorship engagement. However, a large number of firms do not seem to benefit in terms of increasing numbers of business and social relations by joining a network while some report that they do so as a result of their network commitment. From a social capital theory perspective our study reveals that being a member of a network actually enables some firms to form relations with non-members through the mediation of other network members. Hence, the social capital gained through sponsor networks for a minority in our study has the potential to facilitate the acquisition of new knowledge, new resources and access to further information for those firms engaged in it. Accordingly, our study shows that team sport clubs may be able to fulfill an important role in local society beyond being mere entertainment industries. Therefore, building business networks is meant to enhance their attractiveness for sponsors.

\section{Managerial implications for the sport clubs}

That sponsors fit well together with their sponsorship object has always been regarded as a crucial factor in sponsorship creations. At first glance, however, there is often no logical link between corporate strategy and a particular sport organization (Coppetti et al., 2009; Wagner and Nissen, 2015), and as a result, intensive sensemaking is often required in order to create a fit. Involving sponsors, for instance in network activities, is a possible way of making sense of 
a sponsorship. The clubs, and in particular the clubs' managers engaged in sponsor relations, play a crucial role here when we discuss the managerial implications of our findings.

In their extensive review, Ryan and Fahy (2012) claim that contemporary sponsorship management shares many of the characteristics of network management. Although earlier approaches to sponsorships (such as focusing on consumers) still exist, sponsorship as interaction is of more recent origin. Our study builds on this insight by adding an empirical dimension to the network approach. The club management must not only concentrate on the sporting achievements on the pitch but, in addition, be aware of its network orchestration since its sponsors represent a generous financial foundation for the club. This implies that a club's management must operate at various levels (Ryan and Fahy, 2012): it must create a joint vision that is shared by all sponsors while simultaneously creating tailor-made visions for individual sponsors by becoming familiar with their portfolios and how they are related to other companies, including their competitors. This forms the basis for the next step, which is being able to arrange the positions of the companies in the network so that network members are able to benefit from other members' resources and activities. Although our study did not look directly into the management of sponsor networks, the complexity of the managerial implications are also to be considered. As suggested by Ryan and Fahy (2012) we need to look at a sponsorship not so much as a communication tool but "rather more as a platform for engaging in potentially relational forms of communication with consumers and other stakeholders, the management of which incorporates relationship portfolio management practices" (p. 1151). However, managing networks is difficult. A network is loosely coupled, indicating that managing it has some natural limitations (Ritter et al., 2004). Consequently, the term orchestration seems to be the most appropriate concept as it encapsulates the loose interweaving of a network but still emphasizes that a sport club can actively create a network and facilitate business-to-business relations. Rather than sketching a best-practice model, we 
maintain that the sponsorship network should be conceived as a unique platform operated at various levels and should take particular local and regional settings into consideration.

Furthermore, since our study manifests the importance of the network for a local and regional community, local policy makers and regional business planners must integrate sport clubs into their long-term decision making. Again, this underlines that sport clubs play a role beyond being a mere branch of the entertainment industry.

\section{Methodological limitations and research implications}

This study has the status of an exploratory pilot study. Whilst on the one hand it has limitations in terms of scope, on the other hand it clearly points out future research paths. One obvious limitation is that it solely investigates networks connected with two clubs situated in the rural areas of Denmark: the circumstances of top-tier clubs in the major urban areas of Denmark might differ in a variety of ways. This obviously represents a limitation in terms of generalizability. A future step, therefore, could be to extend the study to include all networks associated with the top-tier divisions in handball and football since these two sports - contrary to other less professionalized team sports such as volleyball or basketball - both facilitate and orchestrate sponsor networks. Secondly, this study has not relied on the methodologies used in existing studies which explore trust, commitment and satisfaction in network relations, and as a consequence it has not tested already validated procedures to measure sponsorship relationships (e.g. Farrelly and Quester, 2005). Finally, the study is quantitative. By adding a qualitative methodology and adopting mixed- method approaches, we would be able to say more about the perceptions and motivations of sponsors, the day-to-day nature of networks and how business and personal/private relations interact in network settings. Such approaches would generate knowledge about the balances of power prevailing in sports networks (Wolfe et al., 2002). Qualitative interviews combined with ethnographic observation studies over a 
longer period is recommended if one wishes to understand how the business landscape may be reinvigorated and strengthened by sport clubs. Future studies could benefit by integrating insights from this study into existing research on sponsorship relationships or combining them with more generic studies in relationship marketing, including the methodologies applied within that research field.

Despite these limitations, this study has drawn attention to the role of small and medium-sized businesses in network building with the aim of adding empirically embedded local and regional perspectives to a sponsorship network research that is otherwise dominated by international events and large-scale sponsors. Future research should therefore pay attention to the role and importance of such sport club-facilitated networks, for instance by investigating whether they are able to generate more business-to-business activities and thus contribute to local and regional economic growth and perhaps inter-organizational innovation. These aspects of the networks have not been investigated in our study. Our approach to sport management research on sponsorship is formed by a dialectical view of network establishment. Rather than viewing decision making as either being conducted by a single rational actor unaffected by social context or as being pre-determined by structures, our study invites sport management scholars to perceive sponsorships as dialectical interactive relationships that go beyond methodological individualism and structuralism (for related proposals, see also Chanavat et al. 2016; Cousens et al. 2006; Daellenbach et al. 2006; Olkkonen et al., 2000). From this perspective, the ties between the organizations become the interesting point of departure for further studies.

\section{References}

Amis, J., Slack, T. and Berrett, T. (1999), “Sport Sponsorship as Distinctive Competence”, European Journal of Marketing, Vol. 33 No. 3/4, pp. 250-272. 
Böhler, A. W., Hefferman, T.W. and Hewson, P.J. (2007), “The soccer club-sponsor relationship: identifying the critical variables for success", International Journal of Sports Marketing and Sponsorship, Vol. 8 No. 4, pp. 4-22.

Björnfot, A. and L. Torjussen (2012), "Extent and Effect of Horizontal Supply Chain Collaboration among Construction SME", Journal of Engineering, Project, and Production Management, Vol. 2 No. 1, pp. 47-55.

Brass, D.T., Galaskiewics, J., Greve, H.H., and Tsai, W. (2004), “Taking stock of networks and organizations: A multilevel perspective”, Academy of Management Journal, Vol. 47 No. 6, pp. 795-817.

Brunnetto, Y. and Farr-Wharton, R. (2010), “The Moderate Role of Trust in SME Owner/Mangers’ Decision-Making about Collaboration”, Journal of Small Business Management, Vol. 45 No 3, pp. 362-387.

Capó-Vicedo, J., J. Mula and J. Capó (2011), “A Social Network-Based Organizational Model for Improving Knowledge Management in Supply Chain”, Supply Chain Management: An International Journal, Vol. 16 No. 5, pp. 379-388.

Ceci, F. and D. Iubatti (2012), "Personal relationships and innovation diffusion in SME networks: A content analysis approach", Research Policy, Vol. 41 No 3, pp. 565- 579.

Chadwick, S. and D. Thwaites, (2004), “Advances in the Management of Sport Sponsorship: Fact or Fiction? Evidence form English Professional Soccer", Journal of General Management, Vol. 30 No. 1, pp. 39-60.

Chanavat, N., Desbordes, M. and Dickson, G. (2016), “Sponsorship networks: toward an innovative model”, Sport, Business and Management: An International Journal, Vol. 6 No. 4, pp. 424-439.

Cobbs, J. (2011), “The dynamics of relationship marketing in international sponsorship networks", Journal of Business \& Industrial Marketing, Vol. 26 No. 8, pp. 590-601. 
Coppetti, C., Wentzel, D., Tomczak, T. and Henkel, S. (2009), "Improving incongruent sponsorships through articulation of the sponsorship and audience participation", Journal of Marketing Communications, Vol. 15 No. 1, pp. 17-34.

Cornwell, T.B. (2008), "State of Art and Science in Sponsorship-linked Marketing", Journal of Advertising, Vol. 37 No. 3, pp. 41-55.

Cornwell, T.B. (2014), Sponsorship in marketing. Effective communication through sports, arts and events, Routledge. London, UK.

Cornwell, T. B. and Maignan, I (1998), "Research on sponsorship: International review and appraisal", Journal of Advertising, Vol. 27 No. 2, pp.1-21.

Cousens, L., K. Babiak and C.L. Bradish (2006), “Beyond Sponsorship: Re-framing Corporate-Sport Relationships", Sport Management Review, Vol. 9 No. 1, pp. 1-23.

Daellenbach, K., Davies, J. and Ashill, N.J. (2006), “Understanding sponsorship and sponsorship relationships - multiple frames and multiple perspectives", International Journal of Nonprofit and Voluntary Sector Marketing, Vol. 11 No. 1, pp. 73-87.

Demir R. and Söderman S. (2015), "Strategic sponsoring in professional sport: a review and conceptualization", European Sport Management Quarterly, Vol. 15 No.3, pp. 271-300.

Donovan, T., Carlsson, B. and Zimmermann, M. (2005), “The influence of personality traits on sport fan identification”, Sport Marketing Quarterly, Vol. 14 No. 1, pp 31-42.

Emirbayer, M. (1997), "Manifesto for a relational sociology", American Journal of Sociology, Vol. 103 No. 2, pp. 281-317.

Evens, G. (2003), "Hard-branding the cultural city - from Prado to Prada", International Journal of Urban and Regional Research, Vol. 27 No. 2, pp. 417-440.

Farrelly, F. (2010), “Not playing the Game: Why Sport Sponsorship Relationships Break Down”, Journal of Sport Management, Vol. 24 No. 3, pp. 319-337.

Farrelly, F. and P. Quester, P. (2003), “The effects of market orientation on trust and 
commitment”, European Journal of Marketing, Vol. 37 No. 3-4, pp. 530-553.

Farrelly, F and Quester, P. (2005), “Examining important relationship quality constructs of the focal sponsorship exchange", Industrial Marketing Management, Vol. 34 No. 3, pp. 211-219.

Farrelly, F., Quester, F. and Greyser, S.A. (2005), "Defending the Co-branding Benefits of Sponsorship B2B Partnerships: The Case of Ambush Marketing”, Journal of Advertising Research, Vol. 45 No. 3, pp. 339-348.

Farrelly F, Greyser S and Rogan M (2012), “Sponsorship Linked Internal Marketing (SLIM): A strategic platform for employee engagement and business performance", Journal of Sport Management Vol. 26 No.6, pp. 506-520.

Flöter, T, Benkenstein, M and Uhrich, S (2016), “Communicating CSR-linked sponsorship: Examining the influence of three different types of message sources", Sport Management Review, Vol. 19 No. 2, pp. 146-156.

Giddens, A. (1984), The constitution of society, Cambridge: Polity Press.

Granovetter, M.S. (1973), “The Strength of Weak Ties”, American Journal of Sociology, Vol. 78 No. 6, pp. 1360-1380.

Granovetter, M.S. (1985), “Economic action and social structure: The problem of embeddedness", American Journal of Sociology, Vol. 91 No. 3, pp. 481-510.

Henseler, J., B. Wilson and K. Westberg (2011), “Managers' Perceptions of the Impact of Sport Sponsorship on Brand Equity: Which Aspects of the Sponsorship Matter Most?”, Sport Marketing Quarterly, Vol. 20 No. 1, pp. 7-21.

Human, S.E. and Provan, K.G. (1997), “An Emergent Theory of Structure and Outcomes in Small-Firm Strategic Manufacturing Networks", Academy of Management Journal, Vol. 40 No. 2, pp. 368-403. 
Jørgensen, F. and J.P. Ulhøi (2010), “Enhancing Innovation Capacity in SMEs through Early Network Relationships", Creativity and Innovation Management, Vol. 19 No. 4, pp. $397-404$.

Kim, A.C.H., Lee, H. and Kim, Y. (2014), “Sponsorship network portfolio of corporate partners in the National Basketball Association", International Journal of Sport Management and Marketing, Vol. 15 No 5/6, pp. 340-359.

Kommunernes Landsforening (2014). Danmark i forandring. Udvikling i lokal balance. Copenhagen. Available at: http://www.kl.dk/ImageVaultFiles/id_67022/cf_202/Pixi_Danmark i forandring.PDF (accessed 27 June 2016)

Li, W., R. Veliyath and J. Tan (2013), "Network Characteristics and Firm Performance: An Examination of the Relationships in the Context of a Cluster", Journal of Small Business Management, Vol. 51 No. 1, pp. 1-22.

McGrath, H. and T. O’Toole (2010), “The Potential and Challenge of the Network Realization Capability for SMEs in Ireland and Finland", Journal of Business Market Management, Vol. 4 No.1, pp. 27-49.

Meenaghan, T. (1991), "The Role of Sponsorship in the Marketing Communications mix", International Journal of Advertising, Vol. 10 No. 1, pp. 35-48.

Menaghan, T. (1998), "Current Developments and Future Directions in Sponsorship”, International Journal of Advertising, Vol. 17 No. 1, pp. 3-28.

Miles, L. (2001), “Successful sport sponsorship: Lessons from association football - the role of research", International Journal of Sport Marketing and Sponsorship, Vol. 2 No. 4, pp. 85-97.

Morgan, R.M. and Hunt, S.D. (1994), "The commitment-trust theory of relationship marketing", Journal of Marketing, Vol. 58 No. 3, pp. 20-38. 
Morgan, A., Adair, D., Taylor, T. and Hermens, A. (2014), “Sport sponsorship alliances: relationship management for shared value", Sport, Business \& Management, Vol. 4 No. 4, pp. $270-283$.

Mäläskä, M., S. Saraniemi and J. Tähtinen (2011), "Network Actors’ Participation in B2B SME Branding”, Industrial Marketing Management, Vol. 40 No.7, pp. 1144-1152.

Olkkonen, R. (2001), “Case study: The network approach to international sport sponsorship arrangement”, Journal of Business \& Industrial Marketing, Vol. 16 No. 4, pp. 309-329.

Olkkonen, R., H. Tikkanen and K. Alajoutsijärvi (2000), “Sponsorship as Relationships and Networks", Corporate Communications: An International Journal, Vol. 5 No. 1, 12-18.

O’Malley, L. (2014), “Relational marketing: development, debates and directions”, Journal of Marketing Management, Vol. 30 No. 11-12, pp. 1220-1238.

O’Reilly, N. and Horning, L.F. (2013), “Leveraging sponsorship: The activation ratio”, Sport Management Review, Vol. 16 No. 4, pp. 424-437.

Persson, H.T.R. (2008) "Social capital and social responsibility in Denmark: More than gaining public trust” International Review for the Sociology of Sport, Vol. 43 No. 35, pp. $35-51$.

Pirolo, L. and Presutti, M. (2010), “The impact of social capital on the start-ups' performance growth”, Journal of Small Business Management, Vol. 48 No. 2, pp. 197-227.

Ritter, T., Wilkinson, I. and Johnston, W. (2004), "Managing in complex business networks", Industrial Marketing Management, Vol. 33 No. 3, pp. 175-183.

Rus, A. and Iglic, H. (2005), “Trust, governance and performance: The role of institutional and interpersonal trust in SME development”, International Sociology, Vol. 20 No. 3, pp. 371-391.

Ryan, A. and Fahy, J. (2012), "Evolving priorities in sponsorship: From media management to network management”, Journal of Marketing Management, Vol. 28 No.9-10, pp. 
$1132-1158$

Schoonjans, B., Van Cauwenberge, P and Vander Bauwhede, H. (2013), "Formal business networking and SME growth”, Small Business Economics, Vol. 41 No.1, pp. 169-181

Semrau, T. and A. Werner (2012), "The Two Sides of the Story: Network Investments and New Venture Creation”, Journal of Small Business Management, Vol. 50 No. 1, pp. 159-180.

Slack, T. and L. Bentz (1996), “The Involvement of Small Business in Sport Sponsorship”, Managing Leisure, Vol. 1 No. 3, pp. 175-84.

Storm, R., Thomsen, F. and Jakobsen, T.G. (in press), "Do they make a difference? Professional team sport clubs' effect on migration and local growth: Evidence from Denmark”, Sport Management Review, doi.org/10.1016/j.smr.2016.09.003.

Street, C.T. and A.-F. Cameron (2007), "External Relationships and the Small Business: A Review of Small Business Alliance and Network Research", Journal of Small Business Management, Vol. 45 No. 2, pp. 239-266.

Sullivan, D. and M. Marvel (2011), “How Entrepreneurs' Knowledge and Network Ties Relate to the Number of Employees in New SMEs", Journal of Small Business Management, Vol. 49 No. 2, pp. 185-206.

Tomlinson, P.R. (2011), “Strong Ties, Substantive Embeddedness and Innovation: Exploring Differences in the Innovative Performance of Small and Medium-Sized Firms in UK Manufacturing”, Knowledge and Process Management, Vol. 18 No. 2, pp. 95-108.

Tomlinson, P.R. and F.M. Fai (2013), “The Nature of SME Co-Operation and Innovation: A Multi-Scalar and Multi-Dimensional Analysis", International Journal of Production Economics, Vol. 141 No. 1, pp. 316-312.

Wagner, U. and Nissen, R. (2015), “Enacted ambiguity and risk perceptions: Making sense of national elite sport sponsorships", Sport in Society, Vol. 18 No. 10, pp. 1179-1198. 
Walliser B (2003), “An international review of sponsorship research: extension and update”, International Journal of Advertising, Vol. 22 No. 1, pp. 5-40.

Webster, Jr, F.E. (1992), "The changing role of marketing in the corporation”, Journal of Marketing, Vol. 56 No. 4, pp. 1-17.

Wincent, J., Anokhin, S. and Örtqvist, D. (2010), “Does network board capital matter? A study of innovative performance in SME networks", Journal of Business Research, Vol. 63 No. 3, pp. 265-275.

Wolfe, R., Meenaghan, T. and O'Sullivan, P. (2002), “The sports network: insights into the shifting balance of power", Journal of Business Research, Vol. 55 No. 7, pp. 611-622.

Zinger, J. T. and O'Reilly, N. J. (2010), “An examination of sport sponsorship from a small business perspective. International Journal of Sport Marketing \& Sponsorship, Vol.11 No. 4, pp. 283-301. 


\begin{tabular}{|c|c|c|c|c|c|}
\hline & & $\begin{array}{l}\text { FCV } \\
(\mathrm{N}=67)\end{array}$ & $\begin{array}{l}\text { TS } \varnothing \\
(\mathrm{N}=54)\end{array}$ & Total & $P$-values \\
\hline \multirow{4}{*}{$\begin{array}{l}\text { Number of } \\
\text { employees }\end{array}$} & $0-9$ & $23.9 \%$ & $35.2 \%$ & $32.2 \%$ & \multirow[t]{4}{*}{$p=0.185$} \\
\hline & $10-49$ & $46.3 \%$ & $42.6 \%$ & $41.3 \%$ & \\
\hline & $50-249$ & $16.4 \%$ & $13.0 \%$ & $14.9 \%$ & \\
\hline & 250 or more & $13.4 \%$ & $9.3 \%$ & $11.6 \%$ & \\
\hline \multirow{4}{*}{$\begin{array}{l}\text { Number of } \\
\text { years in the } \\
\text { sponsor } \\
\text { network }\end{array}$} & $<1$ year & $23.9 \%$ & $5.6 \%$ & $15.7 \%$ & \multirow[t]{4}{*}{$p=0.19$} \\
\hline & $1-2$ & $11.9 \%$ & $11.1 \%$ & $11.6 \%$ & \\
\hline & $3-4$ & $17.9 \%$ & $35.2 \%$ & $25.6 \%$ & \\
\hline & $>4$ years & $46.3 \%$ & $48.1 \%$ & $47.1 \%$ & \\
\hline
\end{tabular}

Table 1. The network members' number of employees and the number of years in the sponsor network. 
Table 2. Firms' assessments of eight statements relating to their sponsorship engagement.

\begin{tabular}{|c|c|c|c|c|c|}
\hline $\begin{array}{l}\text { Reasons: } \\
\text { business } \\
\text { or social }\end{array}$ & Items & $\begin{array}{c}\text { Great } \\
\text { influence } \\
(\%)\end{array}$ & $\begin{array}{c}\text { Some } \\
\text { influence } \\
(\%)\end{array}$ & $\begin{array}{c}\text { No } \\
\text { influence } \\
(\%)\end{array}$ & $\begin{array}{c}P \\
\text { (FCV } \\
\text { vs.TS } \varnothing \text { ) }\end{array}$ \\
\hline Business & $\begin{array}{l}\text { We wish to use FCV's/TS } \varnothing \text { 's business network } \\
\text { to make business deals (B2B) }\end{array}$ & 68 & 26 & 6 & 0.054 \\
\hline Social & $\begin{array}{l}\text { We believe it is important to support professional } \\
\text { football/handball on West Zealand/Lolland- } \\
\text { Falster }\end{array}$ & 51 & 38 & 11 & $0.020^{\mathrm{a}}$ \\
\hline Business & $\begin{array}{l}\text { We wish to use FCV/TS } \varnothing \text { to advertise our firm/ } \\
\text { organization and product(s) }\end{array}$ & 45 & 45 & 10 & $0.033^{b}$ \\
\hline Social & $\begin{array}{l}\text { We believe that football/handball is an important } \\
\text { social activity for West Zealand/Lolland-Falster }\end{array}$ & 41 & 46 & 13 & 0.160 \\
\hline Business & $\begin{array}{l}\text { We wish to promote West Zealand/Lolland- } \\
\text { Falster in relation to the rest of Denmark }\end{array}$ & 31 & 44 & 26 & 0.165 \\
\hline Social & $\begin{array}{l}\text { We believe that support for professional } \\
\text { football/handball improves football/handball-4-all }\end{array}$ & 29 & 42 & 28 & 0.081 \\
\hline Business & $\begin{array}{l}\text { We wish to use our sponsorship as part of our } \\
\text { HR work }\end{array}$ & 19 & 46 & 35 & 0.157 \\
\hline Social & $\begin{array}{l}\text { We believe that it has always been important to } \\
\text { support SBI (FCV's mother club) / RH and/or } \\
\text { HMH (TS } \varnothing \text { 's mother clubs) }\end{array}$ & 17 & 47 & 37 & 0.752 \\
\hline
\end{tabular}

${ }^{a} \mathrm{FCV}: 41 \%$ great influence, $44 \%$ some influence, $14 \%$ no influence. TSØ: 63\% great influence, $29 \%$ some influence, $8 \%$ no influence.

${ }^{\mathrm{b}} \mathrm{FCV}$ : $55 \%$ great influence, $34 \%$ some influence, $11 \%$ no influence. TSØ: $32 \%$ great importance, $59 \%$ some influence, $9 \%$ no influence.

Note: The answer category "we do not believe it is like that" was not included in the statistical analyses. This figure was particularly high (14\%) in statement "we believe it has always been important to support professional handball/football. 
Table 3. Firms' assessments of nine statements relating to their participation in FCV/TSØ business network activities.

\begin{tabular}{|c|c|c|c|c|c|}
\hline $\begin{array}{l}\text { Reasons: } \\
\text { business } \\
\text { or social }\end{array}$ & Items & $\begin{array}{c}\text { Great } \\
\text { influence } \\
(\%)\end{array}$ & $\begin{array}{c}\text { Some } \\
\text { influence } \\
(\%)\end{array}$ & $\begin{array}{c}\text { No } \\
\text { influence } \\
(\%)\end{array}$ & $\begin{array}{c}P \\
\text { (FCV } \\
\text { vs.TS } \varnothing \text { ) } \\
\end{array}$ \\
\hline Business & $\begin{array}{l}\text { It provides good opportunities to meet and } \\
\text { speak to other sponsors and business } \\
\text { partners }\end{array}$ & 66 & 32 & 2 & 0.075 \\
\hline Business & It provides opportunities to do business & 61 & 36 & 4 & 0.242 \\
\hline $\begin{array}{l}\text { Social/ } \\
\text { Business }\end{array}$ & $\begin{array}{l}\text { It provides good opportunities to meet new } \\
\text { people }\end{array}$ & 47 & 43 & 10 & 0.343 \\
\hline Business & $\begin{array}{l}\text { It provides good opportunities to hear news } \\
\text { from other companies and/or } \\
\text { entrepreneurs }\end{array}$ & 45 & 50 & 5 & 0.178 \\
\hline Social & It provides good opportunities to socialize & 38 & 54 & 9 & 0.051 \\
\hline Social & $\begin{array}{l}\text { It provides good opportunities to hear news } \\
\text { from FCV/TS } \varnothing\end{array}$ & 21 & 66 & 13 & 0.535 \\
\hline Social & $\begin{array}{l}\text { It provides good opportunities to meet } \\
\text { other people interested in football }\end{array}$ & 14 & 53 & 33 & 0.577 \\
\hline $\begin{array}{l}\text { Social/ } \\
\text { Business }\end{array}$ & $\begin{array}{l}\text { It helps not to miss out on important } \\
\text { information }\end{array}$ & 13 & 59 & 29 & 0.092 \\
\hline Social & $\begin{array}{l}\text { It provides good opportunities for nice food } \\
\text { and drink }\end{array}$ & 11 & 48 & 41 & $0.001^{* * a}$ \\
\hline
\end{tabular}

$* *{ }^{a}$ Great influence: $F C V=2 \% / T S \varnothing=22 \%$; some influence: $F C V=48 \% / T S \varnothing=49 \%$; no influence:

$F C V=51 \% / T S \varnothing=29 \%$.

Note: The answer category "we do not experience it like that" was not included in the statistical analyses. Between $1 \%$ and $4 \%$ reported they did not experience it like that. 


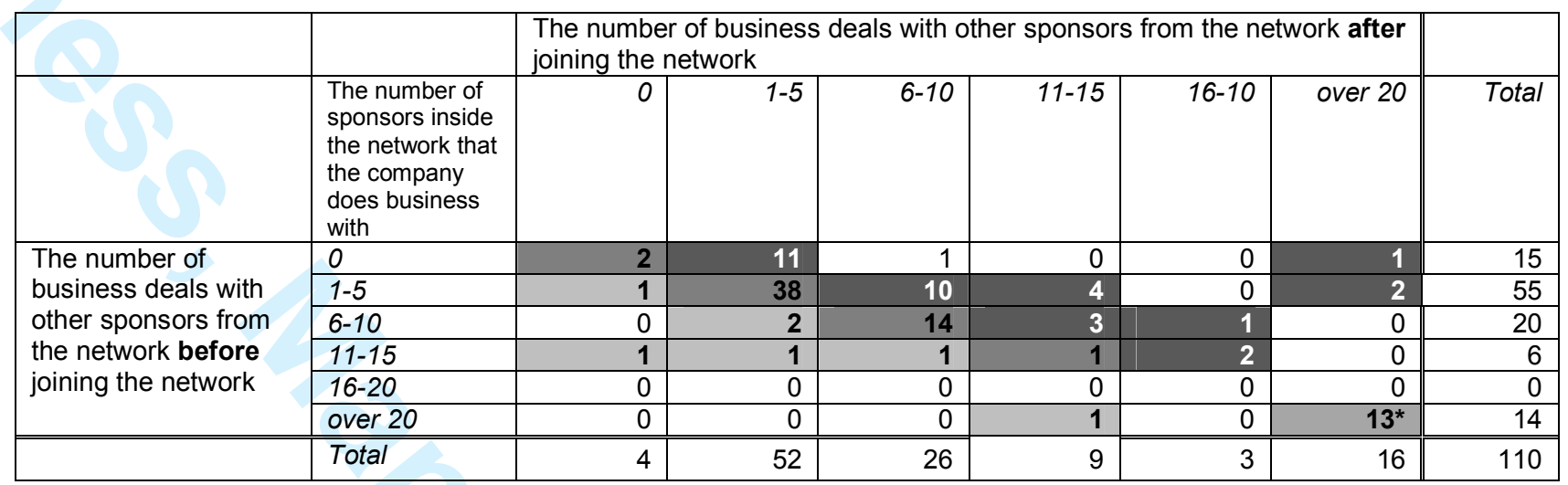

Table 4. The number of business deals with other network members prior to and after joining the networks

Note: * the number of business deals with other sponsor network members may have increased, decreased or remained the same 


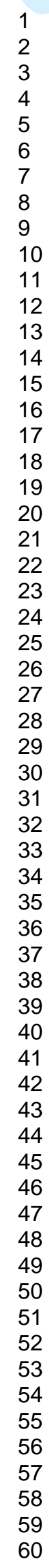




\begin{tabular}{|c|c|c|c|c|c|c|c|}
\hline & & $\begin{array}{l}\text { The numbe } \\
\text { meets up w } \\
\text { network }\end{array}$ & $\begin{array}{l}\text { f persons } \\
\text { on social }\end{array}$ & $\begin{array}{l}\text { ide the net } \\
\text { casions aft }\end{array}$ & $\begin{array}{l}\text { rk "the con } \\
\text { joining the }\end{array}$ & $\begin{array}{l}\text { any" } \\
\text { ponsor }\end{array}$ & \\
\hline & $\begin{array}{l}\text { The number of } \\
\text { persons "the } \\
\text { company" } \\
\text { meets up with } \\
\text { on social } \\
\text { occasions }\end{array}$ & None & $\begin{array}{c}1-3 \\
\text { persons }\end{array}$ & $\begin{array}{c}4-6 \\
\text { persons }\end{array}$ & $\begin{array}{c}7-9 \\
\text { persons }\end{array}$ & $\begin{array}{c}10 \text { or } \\
\text { more } \\
\text { persons }\end{array}$ & Total \\
\hline The number of persons & None & 28 & 7 & 0 & 1 & 1 & 37 \\
\hline inside the network "the & 1-3 persons & 2 & 23 & 8 & 3 & 1 & 37 \\
\hline company" meets up with on & 4-6 persons & 0 & 0 & 12 & 4 & 1 & 17 \\
\hline social occasions before & 7-9 persons & 0 & 1 & 0 & 4 & 2 & 7 \\
\hline joining the sponsor network & $\begin{array}{l}10 \text { or more } \\
\text { persons }\end{array}$ & 0 & 0 & 0 & 0 & $10^{*}$ & 10 \\
\hline & Total & 30 & 31 & 20 & 12 & 15 & 108 \\
\hline
\end{tabular}

Table 5. The number of social relations with other network members prior to and after joining the networks

Note: *The number of private relations with other sponsor network members may have increased, decreased or remained the same. 
Figure 1: Preferences among network members

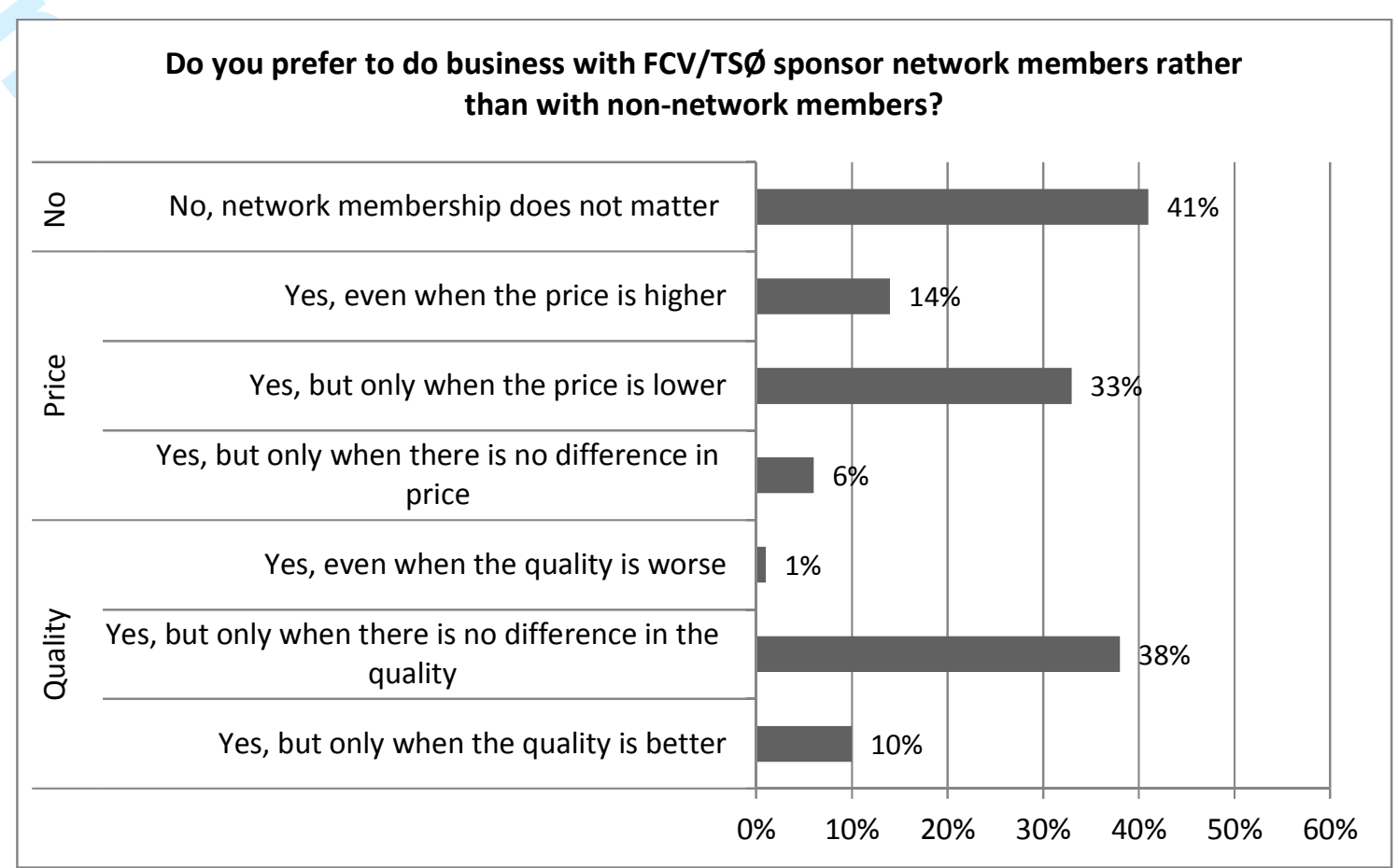

